\title{
Plasma hydroxy-metronidazole/ metronidazole ratio in hepatitis $C$ virus-induced liver disease
}

M.A.M. Marchioretto ${ }^{1}$, C. Ecclissato ${ }^{1}$, C.M.F. da Silva ${ }^{1}$, N.M. Cassiano ${ }^{1}$, S.A. Calafatti' ${ }^{1}$, S. Mendonça ${ }^{1}$, M.L. Ribeiro ${ }^{1}$, G.C.R. Bernasconi ${ }^{1}$,

M.F. Degger ${ }^{1}$, H. Piovesan ${ }^{2}$ and J. Pedrazzoli Jr. ${ }^{1}$
${ }^{1}$ Unidade Integrada de Farmacologia e Gastroenterologia, and ${ }^{2}$ Departamento de Patologia, Faculdade de Medicina, Universidade São Francisco, Bragança Paulista, SP, Brasil

\section{Correspondence}

J. Pedrazzoli Jr.

Unidade Integrada de Farmacologia

e Gastroenterologia

Faculdade de Medicina

Universidade São Francisco

Av. São Francisco de Assis, 218

12916-900 Bragança Paulista, SP

Brasil

Fax: +55-11-4034-1825

E-mail:

pedrazzoli@saofrancisco.edu.br

Research supported by FAPESP

(to J. Pedrazzoli Jr.).

Received June 2, 2003

Accepted November 11, 2004

\begin{abstract}
It has been suggested that the measurement of metronidazole clearance is a sensitive method for evaluating liver function. The aim of this study was to evaluate the usefulness of plasma hydroxy-metronidazole/metronidazole ratios as indicators of dynamic liver function to detect changes resulting from the various forms of chronic hepatitis $\mathrm{C}$ virus (HCV) infection. A total of 139 individuals were studied: 14 healthy volunteers, 22 healthy, asymptomatic, consecutive anti-HCVpositive HCV-RNA negative subjects, 81 patients with chronic hepatitis C (49 with moderate/severe chronic hepatitis and 34 with mild hepatitis), and 20 patients with cirrhosis of the liver. HCV status was determined by the polymerase chain reaction. Plasma concentrations of metronidazole and its hydroxy-metabolite were measured by reverse-phase high-performance liquid chromatography with ultraviolet detection in a blood sample collected $10 \mathrm{~min}$ after the end of a metronidazole infusion. Anti-HCV-positive HCV-RNA-negative individuals demonstrated a significantly reduced capacity to metabolize intravenously infused metronidazole compared to healthy individuals $(0.0478 \pm 0.0044$ vs $0.0742 \pm 0.0232)$. Liver cirrhosis patients also had a reduced plasma hydroxy-metronidazole/metronidazole ratio when compared to the other groups of anti-HCV-positive individuals $(0.0300$ \pm 0.0032 vs $0.0438 \pm 0.0027$ (moderate/severe chronic hepatitis) vs $0.0455 \pm 0.0026$ (mild chronic hepatitis) and vs $0.0478 \pm 0.0044$ (antiHCV-positive, HCV-RNA-negative individuals)). These results suggest an impairment of the metronidazole metabolizing system induced by HCV infection that lasts after viral clearance. In those patients with chronic hepatitis $\mathrm{C}$, this impairment is paralleled by progression of the disease to liver cirrhosis.
\end{abstract}

Key words

- Metronidazole

- Liver function

- Hepatitis C

- Cytochrome P450 


\section{Introduction}

Hepatitis C virus (HCV) is a blood-borne pathogen apparently endemic in most parts of the world (1), and, therefore a major public health problem (2). HVC infection is a frequent cause of chronic liver disease, progressing in the majority of patients to persistent viremia and chronic hepatitis (35). Mortality associated with chronic hepatitis $\mathrm{C}$ results mainly from liver cirrhosis and complications such as liver carcinoma (6). The common course of chronic hepatitis $\mathrm{C}$ involves slow progression. However, the spectrum of liver disease is broad and progression rates are extremely variable $(5,7)$. The long-term outcome is difficult to predict since patients with chronic hepatitis are seldom symptomatic and end-stage liver disease, when it occurs, can take more than three decades to develop (8).

Physical evaluation, the measurement of biochemical parameters, imaging procedures (such as ultrasound or computed tomography) and liver biopsy are used routinely to evaluate chronic HCV carriers and to determine the degree and extension of liver injury and the prognosis of the disease. However, the extent to which these variables estimate hepatic reserve is controversial. Parameters such as albumin and coagulation factors may also be used, but they lack sensitivity and occur late in the course of chronic liver disease $(9,10)$. Thus, a test that could discriminate more subtle impairments of hepatic function would be extremely useful.

Dynamic liver function tests such as indocyanine green clearance (11), caffeine elimination (12) and lidocaine metabolism (13) have been used to complement standard liver assessment in patients with liver disease. Metronidazole clearance has been recently proposed as a highly sensitive method for evaluating liver function (14). This method consists of measuring plasma hydroxy-metronidazole/metronidazole ratio by high-performance liquid chromatography
(HPLC) following the intravenous administration of a single dose of metronidazole. The test has been used to show that antiHCV-positive blood donors and chronic hepatitis $\mathrm{C}$ patients have a decreased capacity to metabolize metronidazole compared to healthy individuals, thus demonstrating its usefulness for detecting impaired liver function in HCV-infected individuals, even in the absence of liver cirrhosis (14). These findings suggest that the evaluation of metronidazole metabolism may provide an easyto-perform, dynamic liver function test. The present study was conducted in order to determine whether the hydroxy-metronidazole/metronidazole test could discriminate between different stages of hepatic functional impairment during the various stages of chronic HCV infection as well as the impact of viral load and genotype on metronidazole metabolism.

\section{Material, Subjects and Methods}

\section{Material}

Metronidazole and tinidazole were purchased from Sigma (St. Louis, MO, USA). Hydroxy-metronidazole was synthesized at Unidade Integrada de Farmacologia e Gastroenterologia, Universidade São Francisco, Bragança Paulista, SP, Brazil. Analytical grade potassium, dihydrogen phosphate, sodium hydroxide, phosphoric acid, and HPLCgrade methanol were obtained from Merck S.A. Indústrias Químicas (Rio de Janeiro, RJ, Brazil). Analytical grade zinc sulfate and tetrahydrofuran were purchased from Reagen (Rio de Janeiro, RJ, Brazil) and Riedel de Haen AG (Seelze, Germany), respectively.

\section{Subjects}

Five groups of subjects were studied: healthy volunteers $(\mathrm{N}=14)$, anti-HCV-positive HCV-RNA-negative individuals $(\mathrm{N}=$ 22), asymptomatic HCV-RNA-positive pa- 
tients $(\mathrm{N}=34)$, patients with $\mathrm{HCV}$-associated chronic hepatitis $(\mathrm{N}=49)$, and patients with $\mathrm{HCV}$-associated liver cirrhosis and preserved liver function $(\mathrm{N}=20)$. All patients with circulating HCV-RNA were submitted to a percutaneous liver biopsy, unless contraindicated.

Patients with abnormal bilirubin, albumin, prothrombin time, ascites, and encephalopathy and/or those diagnosed with liver tumors were excluded from the study. Individuals using drugs which could influence cytochrome P450 function were also excluded.

The clinical protocol was approved by the São Francisco University Ethics Committee, and the study was conducted in accordance with the Declaration of Helsinki. All individuals gave written informed consent prior to entering the study.

\section{Volunteer selection}

Healthy volunteers were enrolled following assessment of their medical history, normal physical examination and laboratory tests, including negative serology for hepatitis $\mathrm{B}$ and $\mathrm{C}$ and the absence of alcoholism. A total of 139 individuals were included in the study: 14 healthy volunteers (males $=11$, median age $=32$ years, range 19-48 years), 22 healthy, asymptomatic, consecutive antiHCV-positive HCV-RNA-negative individuals $($ males $=14$, median age $=37$ years, range 20-63 years), 81 anti-HCV-positive HCVRNA-positive individuals (males $=61$, median age $=36$ years, range $22-62$ years), and 20 liver cirrhosis patients (males $=13$, median age 44, range 29-44 years). Genotype 1 was the most prevalent. Forty-nine patients with circulating HCV-RNA had moderate/ severe chronic hepatitis (males $=37$, median age 38 years, range 23-57 years), and 34 subjects had mild hepatitis (males $=24$, median age 35 years, range 22-62 years) according to the criteria of Desmet et al. (15).

\section{Anti-HCV-positive HCV-RNA-negative individuals}

Asymptomatic, healthy consecutive antiHCV-positive HCV-RNA-negative individuals, without previous treatment for HCV infection, were tested for anti-HCV antibodies using an enzyme immunoassay (Abbott HCV EIA, 2nd generation, Abbott Laboratories Diagnostics Division, Chicago, IL, USA). All positive results were confirmed using a gelatin particle agglutination test with recombinant antigens $\mathrm{C} 22-3$ and $\mathrm{C} 200$ (Serodia-HCV, Fujirebio Inc., Tokyo, Japan). Anti-HCV-positive individuals were considered to have cleared $\mathrm{HCV}$ if serum levels of enzymes synthesized by the liver such as alanine aminotransferase (ALT), aspartate aminotransferase (AST), alkaline phosphatase, and gamma-glutamyl transpeptidase were within the normal reference range, and if no circulating HCV-RNA could be detected by the polymerase chain reaction (PCR). Each patient was tested on three different occasions with at least one month between tests.

\section{Non-cirrhotic hepatopathy}

Anti-HCV-positive HCV-RNA individuals had anti-HCV-positive serum (as measured by EIA, circulating HCV-RNA and persistently abnormal liver enzymes, but no other forms of viral hepatitis (negative serology for HBV). The absence of liver cirrhosis was assessed by clinical evaluation, ultrasonography and/or a CT scan, and was confirmed by a liver biopsy.

\section{HCV-associated liver cirrhosis}

Liver cirrhosis patients were selected for the study based on their medical history, clinical signs and the presence of diffuse alterations in the liver parenchyma detected by ultrasonography or a CT scan. When possible, the diagnosis of cirrhosis was con- 
firmed by a liver biopsy. The patients included were classified as A according to the Child-Pugh scale (11). Patients with liver tumors, an ongoing bacterial infection, or renal failure (as determined by serial serum creatinine determinations) were excluded from the study. The presence of an ongoing bacterial infection was assessed by clinical evaluation, chest radiology and urine analysis.

\section{Clinical laboratory analysis}

Serum chemical analysis, urinalysis, a complete blood cell and platelet count, prothrombin, albumin, serum AST, ALT, alkaline phosphatase, $\gamma$-glutamyl transpeptidase, total bilirubin, prothrombin time, hematocrit, and total/differential white cell counts were determined in all subjects.

\section{Histology}

Biopsy specimens were fixed in $10 \%$ formalin. Sections, 3 to $4 \mu \mathrm{m}$ thick, were cut and stained with hematoxylin-eosin and Masson trichrome or silver for reticulin fibers. For each biopsy specimen, necro-inflammation was graded and the stage of fibrosis was classified according to Desmet et al. (15). The sum of the necro-inflammatory and fibrosis score was considered to be the final score and used to define mild and moderate/severe chronic hepatitis. Chronic hepatitis is defined as mild if the final score was 5 or less and moderate or severe if $>5$.

\section{Plasma hydroxy-metronidazole/metronidazole ratio}

The study consisted of a single intravenous administration of metronidazole (Flagyl ${ }^{\circledR}$, $5 \mathrm{mg} / \mathrm{ml}$, Rhodia, São Paulo, SP, Brazil) for $20 \mathrm{~min}$. At the end of the infusion, the cannula was washed with $20 \mathrm{ml}$ sterile saline. A blood sample $(5 \mathrm{ml})$ was collected from an antecubital vein into EDTA-containing tubes before and $10 \mathrm{~min}$ after the infusion. Blood samples were centrifuged at $2,000 \mathrm{~g}$ for 5 min and plasma was stored at $-20^{\circ} \mathrm{C}$ until assayed. The participants remained in the Clinical Pharmacology Unit during metronidazole administration and blood sampling.

\section{Plasma metronidazole concentration}

The plasma concentrations of metronidazole and its hydroxy-metabolite were measured by a validated reversed-phase HPLC method (14). The separation was performed on a reversed-phase Luna C18 column (250 x $4.6 \mathrm{~mm}$ ID, $10 \mu \mathrm{m}$; Phenomenex, Torrance, CA, USA) protected by a Securityguard C18 guard column $(4.0$ x $3.0 \mathrm{~mm}$; Phenomenex). The mobile phase consisted of $85 \%$ methanol and $15 \% 0.01 \mathrm{M}$ potassium dihydrogen phosphate buffer adjusted to $\mathrm{pH} 4.5$ and was eluted at a flow rate of 1.8 $\mathrm{ml} / \mathrm{min}$. The detector wavelength was set at $324 \mathrm{~nm}$ and peak heights were measured. For the extraction, $50 \mu 1$ of the internal standard (tinidazole, $100 \mu \mathrm{l}$ in methanol) was added to $200 \mu \mathrm{l}$ of plasma. After mixing, deproteinization was carried out by adding $20 \mu 10.6 \mathrm{M} \mathrm{ZnSO}_{4}$ and $20 \mu 10.4 \mathrm{M} \mathrm{NaOH}$. The samples were vortex mixed and the tubes were then centrifuged at $2000 \mathrm{~g}$ for 5 min. Twenty microliters of each supernatant was injected into the HPLC system. The plasma hydroxy-metabolite/metronidazole ratios were determined in all participants. This method has a sensitivity of $100 \mathrm{ng} / \mathrm{ml}$ and the mean intra-assay coefficient of variation (up to $25 \mu \mathrm{g} / \mathrm{ml}$ of both compounds) is $4 \%$.

\section{HCV-RNA detection, quantification and genotyping}

HCV-RNA was extracted from $140 \mu$ of serum with RNA viral QiaAMP (Qiagen, Valencia, CA, USA), reverse transcribed (RT)-PCR and amplified by nested PCR using 5'NCR specific primers 939, 209, 940, 
and 211 as previously described (16). Using the enzymes RsaI-HaeIII and BstNI-HinfI, followed by digestion with $S c r$ FI or Bst $\mathrm{UI}$, we were able to identify and distinguish the HCV genotypes 1a, 1b, 2a, 2b, 3a, 3b, 4, 5, and 6.

Viral load was evaluated by means of real-time quantitative RT-PCR, as previously described (17-19). The use of a sequence detector (ABI Prism 7700; Applied Biosystems, Foster City, CA, USA) allows measurement of the amplified product in direct proportion to the increase in fluorescence emission continuously during PCR amplification. A value above or below $800,000 \mathrm{IU} /$ $\mathrm{ml}$ was used to define a high or low viral load (20).

\section{Statistical analysis}

Data are reported as means \pm SEM unless otherwise stated. All variables were analyzed by one-way ANOVA followed by the Student $t$-test for multiple comparisons among groups, with the level of significance set at $\mathrm{P}<0.001$.

\section{Results and Discussion}

The data in Table 1 show that the plasma hydroxy-metronidazole/metronidazole ratio revealed a reduced capacity of $\mathrm{HCV}$-infected individuals to metabolize intravenously infused metronidazole compared to healthy individuals, regardless of their HCV-RNA status, as indicated by the lower ratio compared to volunteers. Liver cirrhosis patients also had a reduced plasma hydroxy-metronidazole/metronidazole ratio when compared to the other groups of anti HCV-positive individuals (Table 1). The HCV genotype was not related to differences in the plasma hydroxy-metronidazole/metronidazole ratios among patients with chronic hepatitis (Table 2). Similar data for viral load were found $(0.0443 \pm 0.017$ vs $0.0449 \pm 0.0163$ for low and high viral load, respectively; 95\% CI:
$-0.0080 ; 0.0070)$. Therefore, only two groups of patients were formed: individuals with mild hepatic histological alterations and individuals with moderate/severe hepatitis.

Chronic viral hepatitis is a silently progressive disease with a heterogeneous course,

Table 1. Plasma hydroxy-metronidazole/metronidazole ratios 10 min after intravenous administration of $500 \mathrm{mg}$ metronidazole in patients with hepatitis $\mathrm{C}$ virus-induced liver disease.

\begin{tabular}{ll} 
Group & OH-MET/MET ratio \\
\hline Healthy volunteers ( $N=14$ ) & $0.0742 \pm 0.0232$ \\
Anti-HCV-positive HCV-RNA-negative & $0.0478 \pm 0.0207^{*+}$ \\
individuals $(\mathrm{N}=22)$ & $(0.0115 ; 0.0414)^{\mathrm{a}}$ \\
& $(0.0072 ; 0.0029)^{\mathrm{b}}$ \\
Mild chronic hepatitis $(\mathrm{N}=34)$ & $0.0455 \pm 0.0152^{*+}$ \\
& $(0.0154 ; 0.0419)^{\mathrm{a}}$ \\
Moderate/severe chronic hepatitis $(\mathrm{N}=43)$ & $(0.0075 ; 0.0237)^{\mathrm{b}}$ \\
& $0.0438 \pm 0.0187^{*+}$ \\
& $(0.0183 ; 0.0445)^{\mathrm{a}}$ \\
Liver cirrhosis $(\mathrm{N}=20)$ & $(0.0050 ; 0.0207)^{\mathrm{b}}$ \\
& $0.0300 \pm 0.0143^{*}$ \\
& $(0.0306 ; 0.0579)^{\mathrm{a}}$ \\
& $(0.0072 ; 0.0285)^{\mathrm{c}}$
\end{tabular}

Data are reported as means \pm SEM. The numbers in parentheses indicate the upper and lower limits of the $95 \%$ confidence intervals of the significant differences compared to ahealthy volunteers, bpatients with liver cirrhosis and canti-HCV + RNA individuals. OH-MET/MET ratio = hydroxy-metronidazole/metronidazole ratio. ${ }^{*} P<0.001$ vs healthy volunteers, ${ }^{+} P<0.001$ vs patients with liver cirrhosis (one-way ANOVA followed by the Student $t$-test).

Table 2. Plasma hydroxy-metronidazole/metronidazole ratios according to genotype and histological score.

\begin{tabular}{l}
\hline \\
\cline { 2 - 2 } \\
\hline Chronic mild hepatitis
\end{tabular}


making the clinical outcome difficult to predict (7). Since standard liver tests are not useful for predicting the progress of fibrosis in chronic hepatitis patients, a truly quantitative test for liver function could allow a prognostic assessment of various liver diseases (21).

A reliable quantitative liver test would be useful for clinicians and researchers when deciding on therapeutic strategies. The search for such a test has been going on for many years and is complicated by the lack of a universally accepted standard. The formation of monoethylglycinexylidide (MEGX), the main lidocaine metabolite, has been suggested as a simple and valuable liver function test (22-24). However, the administration of lidocaine may produce side effects in a high percentage of individuals tested (22), the formation of MEGX may be influenced by age and gender $(24,25)$, and the lidocaine dose to be administered and the time point for measuring the MEGX concentration are still controversial (26-28). The MEGX test has also failed to discriminate between healthy volunteers and patients with chronic hepatitis $(10,29)$.

The present results demonstrate the ability of the hydroxy-metronidazole/metronidazole ratio to discriminate between healthy individuals and patients with Child-Pugh class A liver cirrhosis, chronic $\mathrm{C}$ hepatitis, or even those with a past HCV infection (Table 2).

Regarding the potential usefulness of the hydroxy-metronidazole/metronidazole ratio in early HCV chronic liver disease, we have shown that this test can discriminate between Child-Pugh class A liver cirrhosis and chronic hepatitis $\mathrm{C}$ or anti-HCV-positive and RNA-negative individuals, but not between the latter patient group and those with chronic hepatitis $\mathrm{C}$, regardless of the severity of the disease (Table 2). These results suggest that $\mathrm{HCV}$ infection, regardless of viral load or genotype, causes abnormalities in liver function, even though viral clearance may have already occurred, and that these abnormalities progress with further progression of liver disease.

Several viral and bacterial infections or interferon-inducing agents have been associated with impaired cytochrome P450-mediated drug metabolism. This effect may be partly mediated by the release of cytokines or related to autoimmune-mediated phenomena which might be triggered by HCV (3037). This immunological imbalance could lead to interference with drug metabolizing systems during the acute phase of hepatitis $\mathrm{C}$ and may persist, even when the infection is self-limited.

Our results indicate an impairment of the metronidazole-metabolizing system induced during the acute phase of $\mathrm{HCV}$ infection. This impairment may continue after viral clearance. In those patients with chronic $\mathrm{C}$ hepatitis, this impairment is paralleled by progression of the disease to liver cirrhosis, indicating that the mechanism of damage is still active and progressive. The hydroxymetronidazole/metronidazole ratio was sensitive enough to discriminate among normal individuals and those with a past or an ongoing $\mathrm{HCV}$ infection, confirming our previous report (14), but could not discriminate those individuals with a history of $\mathrm{HCV}$ infection from those harboring a chronic hepatitis and thus, at risk for a progressive liver disease. Therefore, the usefulness of this test in the clinical setting needs to be further evaluated. 


\section{References}

1. Wasley A \& Alter MJ (2000). Epidemiology of hepatitis C: geographic differences and temporal trends. Seminars in Liver Disease, 20: 1-16.

2. Wiese M, Berr F, Lafrenz $M$, Porst $H$ \& Oesen U (2000). Low frequency of cirrhosis in a hepatitis $C$ (genotype $1 \mathrm{~b}$ ) single-source outbreak in Germany: a 20-year multicenter study. Hepatology, 32: 91-96.

3. Alter MJ, Margolis HS, Krawczinski K et al. (1992). The natural history of community-acquired hepatitis $\mathrm{C}$ in the United States. The sentinel counties chronic non-A, non-B hepatitis study team. New England Journal of Medicine, 327: 1899-1905.

4. National Institutes of Health Consensus Development Conference Panel Statement (1997). Management of hepatitis C. Hepatology, 26 (Suppl 1): 2S-10S.

5. EASL International Consensus Conference on Hepatitis C (1999). Consensus Conference. Journal of Hepatology, 30: 956-961.

6. Poynard T, Bedossa P \& Opolon P (1997). Natural history of liver fibrosis progression in patients with chronic hepatitis $\mathrm{C}$. The Obsvirc, Metavir, Clinivir, and Dosvirc groups. Lancet, 349: 825-832.

7. Alberti $A$, Chemello $L \&$ Benvegnu $L$ (1999). Natural history of hepatitis C. Journal of Hepatology, 31 (Suppl 1): 17-24.

8. Tong MJ, el-Farra NS, Reikes AR \& Co RL (1995). Clinical outcome after transfusion-associated hepatitis C. New England Journal of Medicine, 332: 1463-1466.

9. Herold C, Heinz R, Niedobitek G, Schneider T, Hahn EG \& Schuppan $D$ (2001). Quantitative testing of liver function in relation to fibrosis in patients with chronic hepatitis B and C. Liver, 21: 260-265.

10. Elin RJ, Fried MW, Sampson M, Ruddel M, Kleiner DE \& DiBisceglie AM (1997). Assessment of monoethylglycinexylidide as measure of liver function for patients with chronic viral hepatitis. Clinical Chemistry, 43: 1952-1957.

11. Albers I, Hartmann H, Bircher J \& Creutzfeldt W (1989). Superiority of the Child-Pugh classification to quantitative liver function tests for assessing prognosis of liver cirrhosis. Scandinavian Journal of Gastroenterology, 24: 269-276.

12. Wang $T$, Kleber G, Stellaard F \& Paumgartner G (1985). Caffeine elimination: a test of liver function. Klinische Wochenschrift, 63: 1124-1128.

13. Shiffman ML, Fisher RA, Sanyal AJ, Edinboro LE, Luketic VA, Purdum 3rd PP, Raymond P \& Posner MP (1993). Hepatic lidocaine metabolism and complications of cirrhosis. Implications for assessing patient priority for hepatic transplantation. Transplantation, 55: 830-835.

14. da Silva CMF, David FL, Muscara MN, Sousa SS, Ferraz JG, de Nucci G, Polimeno NC \& Pedrazzoli Jr J (1998). Plasma hydroxy metronidazole/metronidazole ratio in anti-HCV carriers with and without apparent liver disease. British Journal of Clinical Pharmacology, 46: 176-180.

15. Desmet VJ, Gerber M, Hoofnagle JH, Manns M \& Scheuer PJ (1994). Classification of chronic hepatitis: diagnosis, grading and staging. Hepatology, 19: 1513-1520.

16. Chan SW, McOmish F, Holmes EC, Dow B, Peutherer JF, Follett E, Yap PL \& Simmonds P (1992). Analysis of a new hepatitis $C$ virus type and its phylogenetic relationship to existing variants. Journal of General Virology, 73 (Part 5): 1131-1141.

17. Holland PM, Abramson RD, Watson R \& Gelfand DH (1991). Detection of specific polymerase chain reaction product by utilizing the 5'3'-exonuclease activity of thermus aquaticus DNA polymerase. Proceedings of the National Academy of Sciences, USA, 88: 7276-
7280.

18. Bukh J, Purcell RH \& Miller RH (1994). Sequence analysis of the core gene of 14 hepatitis $C$ virus genotypes. Proceedings of the National Academy of Sciences, USA, 91: 8239-8243.

19. Smith DB, Mellor J, Jarvis LM, Davidson F, Kolberg J, Urdea M, Yap PL \& Simmonds P (1995). Variation of the hepatitis C virus 5'noncoding region: implications for secondary structure, virus detection and typing. The International HCV Collaborative Study Group. Journal of General Virology, 76 (Part 7): 1749-1761.

20. Pawlotsky JM, Bouvier-Alias M, Hezode C, Darthuy F, Remire J \& Dhumeaux D (2000). Standardization of hepatitis C virus RNA quantification. Hepatology, 32: 654-659.

21. Mion F, Rosseau M, Scoazec JY, Berger F \& Minaire Y (1999). [C ${ }^{13}$ ]Galactose breath test: correlation with liver fibrosis in chronic hepatitis C. European Journal of Clinical Investigation, 29: 624-629.

22. Shiffman ML, Luketic VA, Sanyal AJ, Duckworth PF, Purdum 3rd PP, Contos MJ, Mills AS, Edinboro LE \& Poklis A (1994). Hepatic lidocaine metabolism and liver histology in patients with chronic hepatitis and cirrhosis. Hepatology, 19: 933-940.

23. Huang YS, Lee SD, Deng JF, Wu JC, Lu RH, Lin YF, Wang YJ \& Lo KJ (1993). Measuring lidocaine metabolite-monoethylglycinexylidide as a quantitative index of hepatic function in adults with chronic hepatitis and cirrhosis. Journal of Hepatology, 19: 140-147.

24. Testa R, Caglieris S, Risso D, Arzani L, Campo N, Alvarez S, Giannini E, Lantieri PB \& Celle G (1997). Monoethylglycinexylidide formation measurement as a hepatic function test to assess severity of chronic liver disease. American Journal of Gastroenterology, 92: 2268-2273.

25. Orlando R \& Palatini $P$ (1997). The effect of age on plasma MEGX concentrations. British Journal of Clinical Pharmacology, 44: 206208.

26. Fabris L, Jemmolo RM, Toffolo $G$ et al. (1999). The monoethylglycinexylidide test for grading of liver cirrhosis. Alimentary Pharmacology and Therapeutics, 13: 67-75.

27. Reichel C, Wienkoop G, Nacke A, Sudhop T, Spengler U \& Sauerbruch T (1995). Which lidocaine dose should be used for the MEGX liver function test? Journal of Hepatology, 22: 600.

28. Reichel C, Nacke A, Sudhop T, Wienkoop G, Luers C, Hahn C, Pohl C, Spengler U \& Sauerbruch T (1997). The low-dose monoethylglycinexylidide test: assessment of liver function with fewer side effects. Hepatology, 25: 1323-1327.

29. Testa R, Campo N, Caglieris S, Risso D, Alvarez S, Arzani L, Giannini E, Lantieri PB \& Celle G (1998). Lidocaine elimination and monoethylglycinexylidide formation in patients with chronic hepatitis or cirrhosis. HepatoGastroenterology, 45: 154-159.

30. Renton KW \& Knickle LC (1990). Regulation of hepatic cytochrome P-450 during infectious disease. Canadian Journal of Physiology and Pharmacology, 68: 777-781.

31. Thal C, el Kahwaji J, Loeper J, Tinel M, Doostzadeh J, Labbe G, Leclaire J, Beaune P \& Pessayre D (1994). Administration of high doses of human recombinant interleukin-2 decreases the expression of several cytochromes P-450 in the rat. Journal of Pharmacology and Experimental Therapeutics, 268: 515-521.

32. Abdel-Razzak Z, Loyer P, Fautrel A, Gautier JC, Corcos L, Turlin B, Beaune P \& Guillouzo A (1993). Cytokines down-regulate expression of major cytochrome P-450 enzymes in adult human hepatocytes in primary culture. Molecular Pharmacology, 44: 707-715.

33. Tapner M, Liddle C, Goodwin B, George J \& Farrell GC (1996). Interferon gamma down-regulates cytochrome P-450 3A genes in 
primary cultures of well-differentiated rat hepatocytes. Hepatology, 24: 367-373.

34. Lunel F, Abuaf N, Frangeul L et al. (1992). Liver/kidney microsome antibody type 1 and hepatitis C virus infection. Hepatology, 16: 630636.

35. Tran A, Quaranta JF, Benzaken S et al. (1993). High prevalence of thyroid autoantibodies in a prospective series of patients with chronic hepatitis C before interferon therapy. Hepatology, 18: 253257.
36. Michel G, Ritter A, Gerken G, Meyerzum Buschenfelde KH, Decker R \& Manns MP (1992). Anti-GOR and hepatitis C virus in autoimmune liver diseases. Lancet, 339: 267-268.

37. Kammer AR, van der Burg SH, Grabscheid B, Hunziker IP, Kwappenberg KM, Reichen J, Melief CJ \& Cerny A (1999). Molecular mimicry of human cytochrome $\mathrm{P}-450$ by hepatitis $\mathrm{C}$ virus at the level of cytotoxic T cell recognition. Journal of Experimental Medicine, 190: 169-176. 